\title{
THE MEASUREMENT AND METABOLISM OF THIAMIN AND OF A PYRIMIDINE STIMULATING YEAST FERMENTATION FOUND IN THE BLOOD CELLS AND URINE OF PATIENTS WITH LEUKEMIA ${ }^{1}$
}

\author{
By JULES C. ABELS,2 ALICE T. GORHAM, LLOYD CRAVER, \\ AND C. P. RHOADS \\ (From the Memorial Hospital for the Treatment of Cancer and Allied Diseases, \\ New York City)
}

(Received for publication November 17, 1941)

In a previous communication (1) methods were presented for the measurement, in blood cells and urine, of thiamin and of the pyrimidine accelerator of yeast fermentation (PAYF), as well as the results of the application of these methods in a study of the metabolism of the vitamin by the leukocytes and platelets of human beings. It was pointed out that, since thiamin and the PAYF, a probable metabolite of the vitamin, were distributed unequally among the cellular elements of blood, and since the proportions of these elements vary, a comparison of the levels of those substances in the whole blood of normal subjects with those of patients with leukemia would not be valid.

The concentrations of free thiamin (2) and of cocarboxylase (3) in the whole blood of leukemic individuals have been reported to be elevated occasionally, even though no corrections were made for the abnormal red or white cell counts. Furthermore, Butler and Cushman have shown that leukemic white cells have an abnormally high content of ascorbic acid (4). Hence, it was deemed important to determine whether or not leukemic white cells contain abnormally high concentrations of thiamin.

The study here reported was undertaken, therefore, (1) to compare, by the method described, the levels of thiamin and of the PAYF in unit volumes of leukemic and normal leukocytes and platelets, erythrocytes, and urine, and (2) to compare the metabolism of the vitamin in normal individuals with that in patients with leukemia.

\section{CLINICAL MATERIAL AND METHODS}

Four groups of patients were studied. The first comprised 33 individuals with leukemia who were selected

1 This investigation was aided by a grant from the Jane Coffin Childs Memorial Fund for Medical Research, and the Standard Brands, Inc.

2 Finney-Howell Fellow. from 55 consecutive admissions to the medical service of the Memorial Hospital for the Treatment of Cancer and Allied Diseases. The other 21 patients were rejected as unsuitable because they had received thiamin therapeutically just before their admission.

The diagnosis of leukemia was made in all instances by the usual criteria of physical findings and examination of the blood and bone marrow. Of the 33 patients, 17 had myeloid, 14 lymphoid, 1 eosinophilic, and 1 monocytic leukemia. One patient with myeloid and 4 with lymphoid leukemia were in an acute phase of their disease; and 1 with myeloid and 2 with lymphoid leukemia presented the aleukemic form. All of the other patients had welladvanced chronic disease with leukocyte counts which ranged from 40,000 to 400,000 per cmm. None had received any form of medication other than $x$-radiation, and this had been administered only to 7 .

The second group was composed of 8 patients with Hodgkin's disease. The diagnosis in each instance was proved by the microscopic examination of a node removed at biopsy. All 8 individuals had considerable enlargement of four or more groups of nodes, but only 1 had enough abdominal lymphadenopathy to produce symptoms.

The third group represented 24 routine admissions to the gastric and rectal services of the institution. Of these 24 patients, 18 had cancer of the stomach and 6 had cancer of the colon.

The fourth group consisted of 5 patients with cirrhosis of the liver. All of these had well-advanced disease, with hepatomegaly, ascites, and jaundice. Of the 5, 1 had vomited for about 4 weeks before admission.

None of the patients in the various groups had received supplements of thiamin during the 20 days which preceded the determinations of the thiamin concentration of their blood cells and urine. All of the patients had been on adequate normal diets for at least 1 week before the thiamin assays were made.

The methods for the determination of thiamin and of PAYF used in the investigation are described in the previous communication (1). In the present communication, the term "white cells" is employed to include both leukocytes and platelets. It should be noted that, in contrast to normal white cells, the leukemic cells are readily obtained from whole blood for the measurement of their content of thiamin and of PAYF. 
The term "total thiamin" is used to include all these substances capable of stimulating fermentation by yeast under the conditions of the experimental procedure. The values of PAYF are expressed in micrograms of thiamin which have an equivalent yeast-stimulating activity. The true thiamin finally is calculated as the difference between total thiamin and the PAYF.

\section{RESULTS}

The results are presented in two parts: $(A)$ The levels of thiamin and PAYF in the blood cells and urine of patients with leukemia and other diseases; and $(B)$ Evidence by which the abnormal concentrations of these substances can be explained.

\section{A. The levels of thiamin and PAYF in the blood cells and urine of patients with leu- kemia and other diseases}

1. The total thiamin concentrations in the white cells of patients with leukemia. The concentrations of total thiamin in the white cells of $33 \mathrm{pa}$ tients with leukemia ranged from 85 to 600 micrograms per $100 \mathrm{ml}$. of cells. The average value was 277 micrograms per $100 \mathrm{ml}$., or about 3 times the normal average (normal average is 100 micrograms). Of the 33 patients, 27 or 82 per cent, had white cell total thiamin levels above the highest normal (normal range is from 48 to 183 micrograms per $100 \mathrm{ml}$.) (Table I, Figures 1 and 2).

Of the 33 patients, 18 with myeloid leukemia had white cell thiamin concentrations which ranged from 85 to 600 micrograms per $100 \mathrm{ml}$. and averaged 296 micrograms per $100 \mathrm{ml}$. This group of patients included a child with chronic eosinophilic leukemia whose white cell thiamin value was 350 micrograms per $100 \mathrm{ml}$. of cells.

Fourteen individuals with lymphatic leukemia had white cell total thiamin levels from 160 to 520 micrograms per cent, and averaged 270 micrograms per cent. The 1 adult with chronic monocytic leukemia had a total thiamin level of 345 micrograms per $100 \mathrm{ml}$. of white cells.

The frequency with which high levels of white cell thiamin were encountered in patients with leukemia suggested immediately that the levels might reflect the type or severity of the disease or the comparative youth of the cell types affected. No such correlation could be established. Of the 33 patients, 1 with myeloid and 4 with lymphoid leukemia (Table II) were in an acute phase of the disease marked by a predominance of blast forms. The white cells of these patients showed no greater concentrations of total thiamin than were found in the cells of patients with chronic forms of the disorder marked by more mature cellular elements.

TABLE I

Micrograms of total thiamin, true thiamin and of PAYF* per $100 \mathrm{ml}$. of blood cells of patients with leukemia

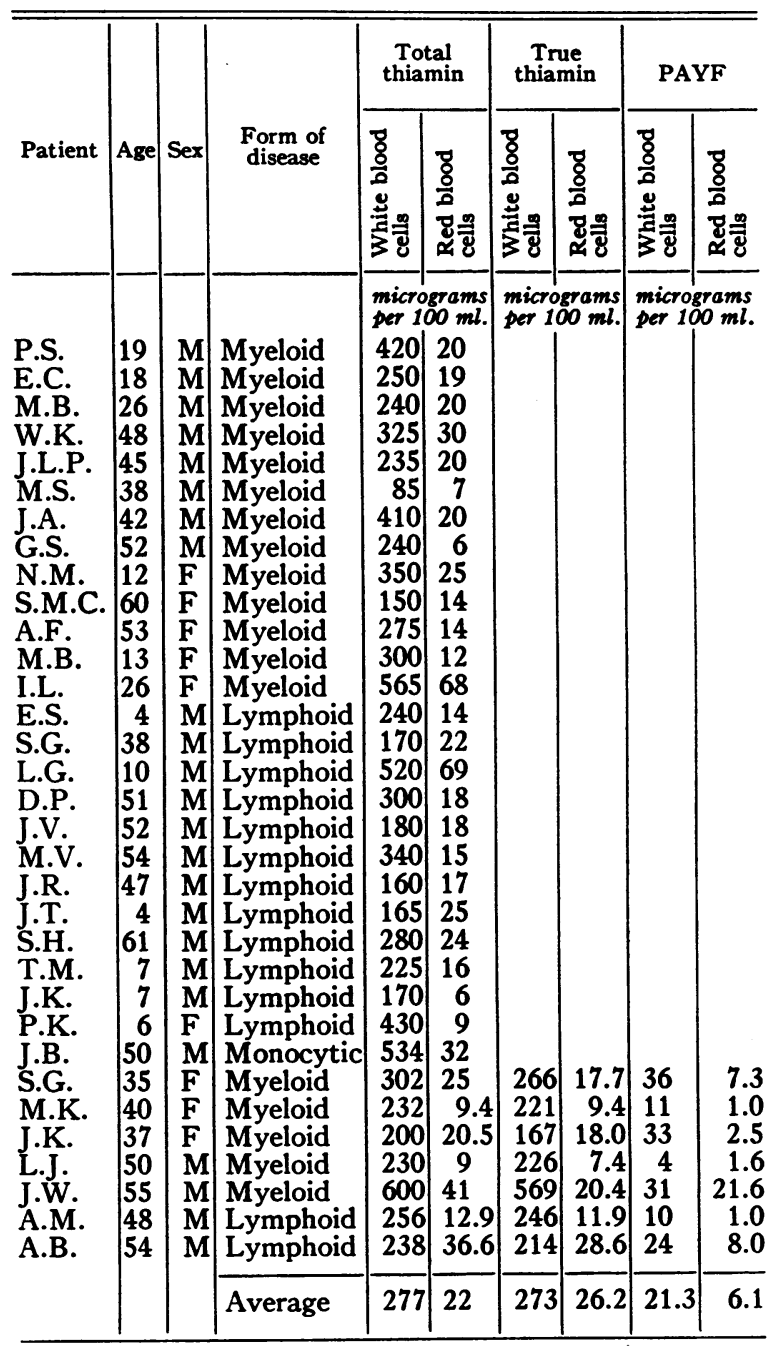

* Expressed in thiamin equivalents.

The white cell thiamin of the group with acute leukemia varied from 220 to 425 micrograms per $100 \mathrm{ml}$. of cells and averaged 277 micrograms per $100 \mathrm{ml}$., whereas that of the remainder of the patients with chronic leukemia ranged from 83 to 600 micrograms per $100 \mathrm{ml}$., and averaged 272 micrograms per $100 \mathrm{ml}$. 
Three patients with lymphoid leukemia were in these 3 also had high white cell total thiamin an aleukemic phase. Although the disorder in levels: 165, 240 and 280 micrograms per cent. $\begin{array}{ll}\text { these patients was marked by relatively few appar- } & \text { 2. The PAYF concentrations in the white cells }\end{array}$ ently immature circulating leukocytes (Table III), of patients with leukemia. The levels of PAYF

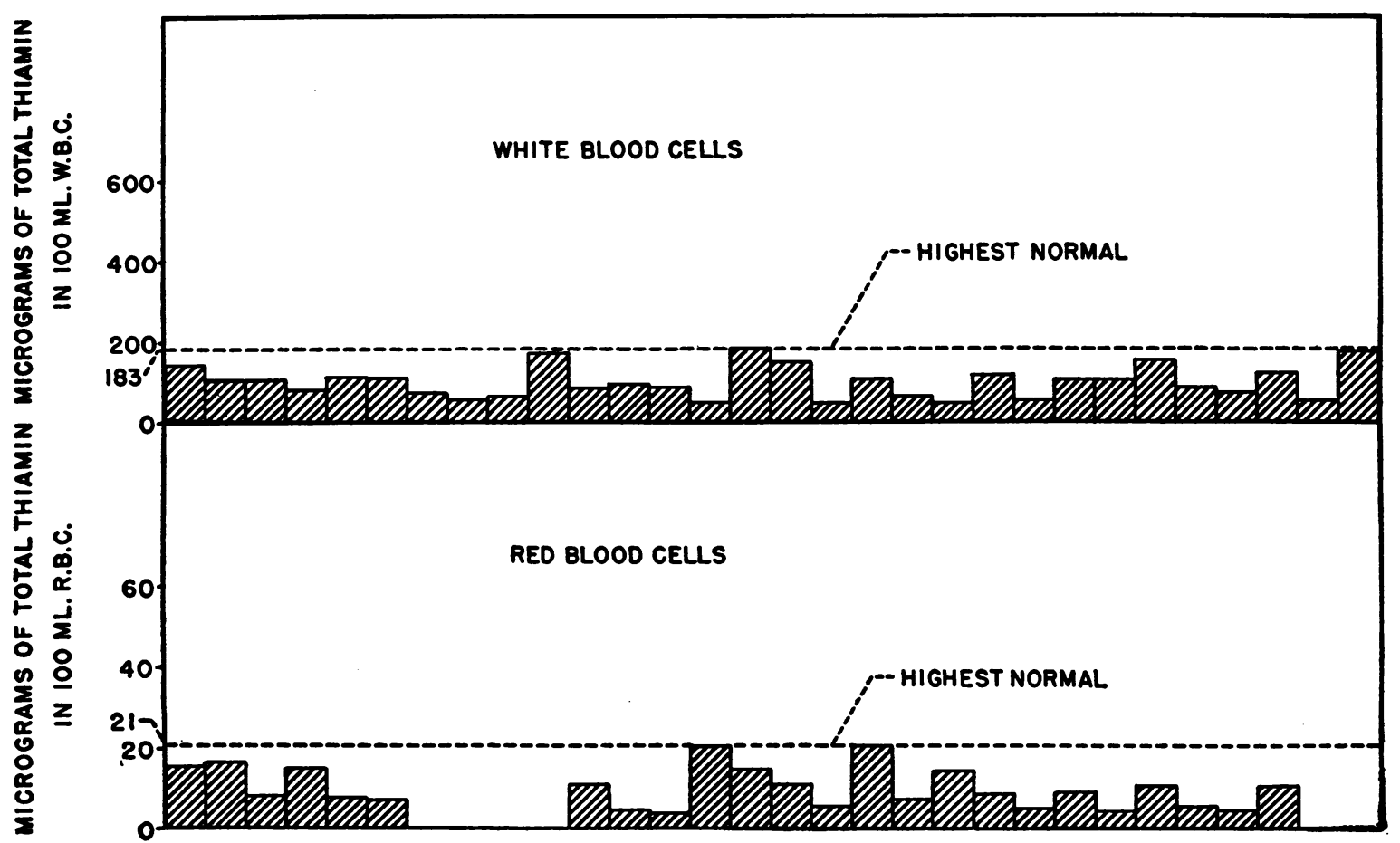

Fig. 1. The Levels of Total Thiamin in the Blood Cells of Normal Individuals

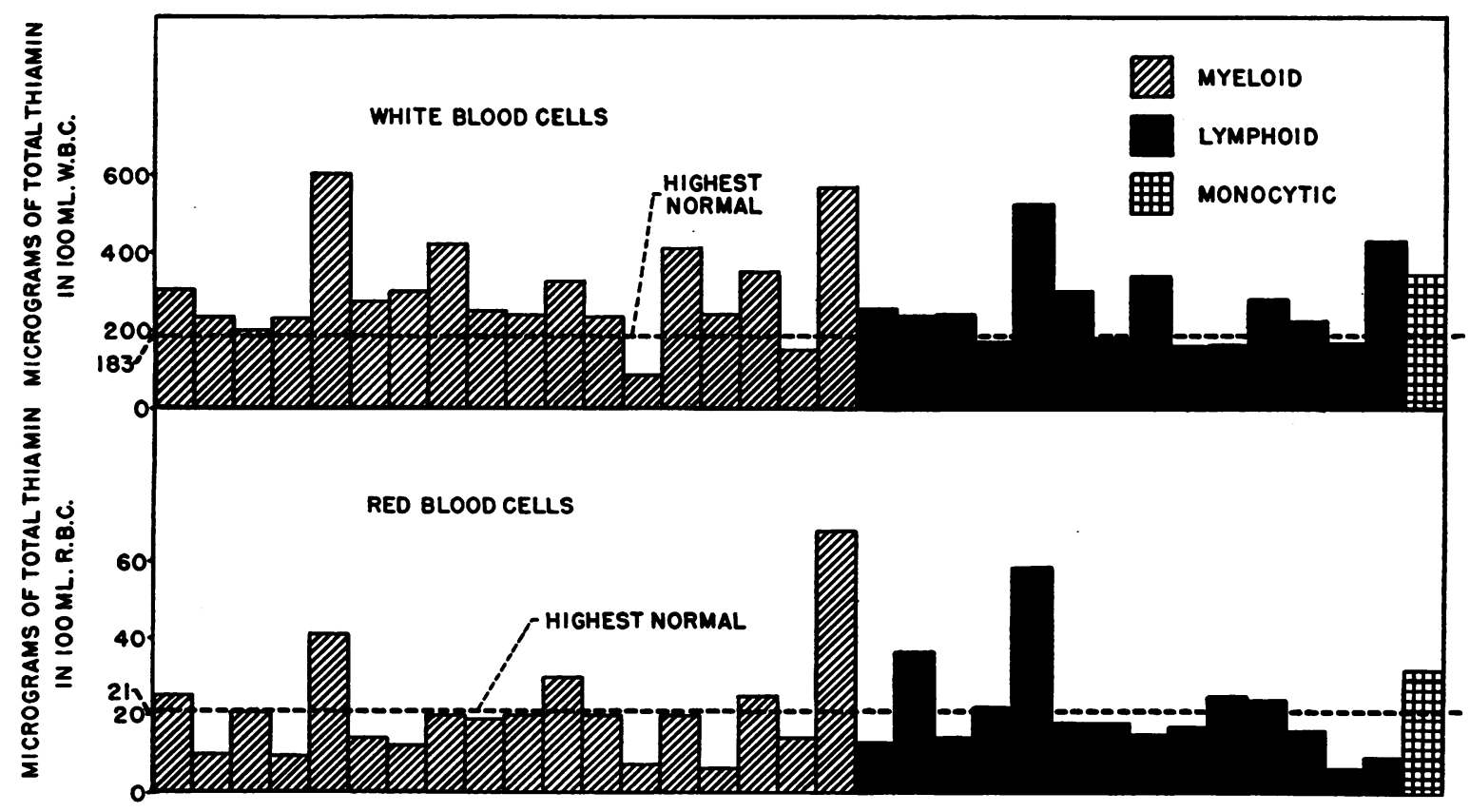

Fig. 2. The Levels of Total Thiamin in the Blood Cells of Patients with Leukemia 
TABLE II

The blood cell content of total thiamin of patients with acute leukemia

\begin{tabular}{|c|c|c|c|c|c|}
\hline \multirow{2}{*}{ Patient } & \multirow{2}{*}{ Form } & \multirow{2}{*}{ Blood count } & \multirow{2}{*}{ Marrow } & \multicolumn{2}{|c|}{ Total thiamin } \\
\hline & & & & $\begin{array}{l}\text { White blood } \\
\text { cells }\end{array}$ & $\begin{array}{l}\text { Red blood } \\
\text { cells }\end{array}$ \\
\hline E. C. & Myeloid & $\begin{array}{l}\text { Red blood cells } 2.21, \text { Hemoglobin } 42 \% \\
\text { White blood cells } 31,600 \\
\text { Myeloblasts } 60 \% \\
\text { Myelocytes } 15 \% \\
\text { Polymorphonuclear leukocytes } 18 \% \\
\text { Lymphocytes } 7 \%\end{array}$ & $\begin{array}{c}\text { Myeloblasts } \\
\mathbf{8 5 \%}\end{array}$ & $\begin{array}{l}\text { micrograms } \\
250\end{array}$ & $\begin{array}{c}\text { per } 100 \mathrm{ml} . \\
20\end{array}$ \\
\hline E. S. & Lymphoid & $\begin{array}{l}\text { Red blood cells } 1.50, \text { Hemoglobin } 32 \% \\
\text { White blood cells } 2800 \\
\text { Lymphoblasts } 80 \% \\
\text { Polymorphonuclear leukocytes } 20 \%\end{array}$ & $\begin{array}{c}\text { Lymphoblasts } \\
100 \%\end{array}$ & 240 & 14 \\
\hline P. C. & Lymphoid & $\begin{array}{l}\text { Red bood cells } 3.75 \text {, Hemoglobin } 40 \% \\
\text { White blood cells } 57,200 \\
\text { Lymphoblasts } 90 \% \\
\text { Polymorphonuclear leukocytes } 5 \% \\
\text { Monocytes } 5 \%\end{array}$ & $\begin{array}{c}\text { Lymphoblasts } \\
100 \%\end{array}$ & 425 & 9 \\
\hline A. B. & Lymphoid & $\begin{array}{l}\text { Red blood cells } 2.44, \text { Hemoglobin } 45 \% \\
\text { White blood cells } 160,000 \\
\text { Lymphoblasts } 100 \%\end{array}$ & $\begin{array}{c}\text { Lymphoblasts } \\
100 \%\end{array}$ & 220 & 30 \\
\hline \multirow[t]{2}{*}{ E. D. } & \multirow[t]{2}{*}{ Lymphoid } & $\begin{array}{l}\text { Red blood cells } 3.04 \text {, Hemoglobin } 61 \% \\
\text { White blood cells } 31,000 \\
\text { Lymphoblasts } 98 \% \\
\text { Polymorphonuclear leukocytes } 2 \%\end{array}$ & $\begin{array}{c}\text { Lymphoblasts } \\
100 \%\end{array}$ & 250 & 14 \\
\hline & & & Average & 277 & 17.6 \\
\hline
\end{tabular}

TABLE III

Total thiamin in the blood cells of patients with aleukemic leukemia

\begin{tabular}{|c|c|c|c|c|c|}
\hline \multirow[b]{2}{*}{ Patient } & \multirow[b]{2}{*}{ Form } & \multirow[b]{2}{*}{ Blood } & \multirow[b]{2}{*}{ Marrow } & \multicolumn{2}{|c|}{ Total thiamin } \\
\hline & & & & $\begin{array}{l}\text { White } \\
\text { blood } \\
\text { cells }\end{array}$ & $\begin{array}{l}\text { Red } \\
\text { blood } \\
\text { cells }\end{array}$ \\
\hline S. H. & $\begin{array}{l}\text { Chronic } \\
\text { lymphoid }\end{array}$ & $\begin{array}{l}\text { Red blood cells } 1.76 \text {, Hemoglobin } 39 \% \\
\text { White blood cells } 4600 \\
\text { Lymphocytes } 81 \% \\
\text { Polymorphonuclear leukocytes } 12 \% \\
\text { Monocytes } 7 \%\end{array}$ & $\begin{array}{l}\text { Lymphoblasts } 10 \% \\
\text { Lymphocytes } 60 \%\end{array}$ & $\begin{array}{c}\text { micrograms } \\
280\end{array}$ & $\begin{array}{c}\text { per } 100 \mathrm{ml} . \\
24\end{array}$ \\
\hline J. T. & $\begin{array}{l}\text { Chronic } \\
\text { lymphoid }\end{array}$ & $\begin{array}{l}\text { Red blood cells } 3.42 \text {, Hemoglobin } 57 \% \\
\text { White blood cells } 5800 \\
\text { Lymphocytes } 68 \% \\
\text { Polymorphonuclear leukocytes } 26 \% \\
\text { Monocytes } 6 \%\end{array}$ & $\begin{array}{l}\text { Lymphoblasts } 16 \% \\
\text { Lymphocytes } 58 \%\end{array}$ & 165 & 25 \\
\hline \multirow[t]{2}{*}{ C. S. } & \multirow[t]{2}{*}{$\begin{array}{l}\text { Chronic } \\
\text { lymphoid }\end{array}$} & $\begin{array}{l}\text { Red blood cells } 3.23 \text {, Hemoglobin } 72 \% \\
\text { White blood cells } 5500 \\
\text { Polymorphonuclear leukocytes } 63 \% \\
\text { Metamyelocytes } 5 \% \\
\text { Monocytes } 8 \% \\
\text { Lymphocytes } 8 \%\end{array}$ & $\begin{array}{l}\text { Myeloblasts } 4 \% \\
\text { Myelocytes } 40 \%\end{array}$ & 240 & 12 \\
\hline & & . & Average & 228 & 27.3 \\
\hline
\end{tabular}


were determined in the leukocytes and platelets of 7 of the 34 patients with all forms of leukemia (Table I). These levels ranged from 4 to 36 micrograms and averaged 21 micrograms per 100 $\mathrm{ml}$. It is interesting that, whereas the PAYF formed from 16.8 per cent to 64.0 per cent (average 30.5 per cent) of the total thiamin of normal white cells, in the leukemic white cells that substance represented only from 2.0 to 16.5 per cent (average 7.7 per cent) of the total thiamin. It should be noted that no leukemic patient showed a per cent PAYF of the total thiamin as high as that of the lowest normal (16.8 per cent).

3. The total thiamin concentration in the erythrocytes of patients with leukemia. The total thiamin levels in the red cells were determined in all of the 33 patients with leukemia (Table I). In general, these levels were higher than the concentrations of total thiamin in normal red cells (1), but were not as abnormally elevated as were the levels in the leukemic white cells. The total thiamin concentrations in the erythrocytes of the patients with leukemia varied from 6 to 69 micrograms and averaged 22 micrograms per $100 \mathrm{ml}$., or about twice the normal value (normal average 10.0 micrograms). Of the 33 patients, 11 , or 32 per cent, had erythrocyte total thiamin levels above the highest normal value, and 28 , or 82 per cent, had levels above the normal average. The frequency with which elevated erythrocyte thiamin levels were encountered is further evidence against the view that the abnormally high levels in leukemic leukocytes reflect simply the immaturity of the cells.

No apparent correlation has been found between the erythrocyte level of total thiamin and the form or severity of the leukemic process.

In the 18 patients with myeloid leukemia whose erythrocyte thiamin levels were determined, those levels varied from 6 to 68 micrograms and averaged 21 micrograms per cent. Similarly, in the 14 patients with lymphoid leukemia, the erythrocyte levels of total thiamin ranged from 6 to 69 micrograms and averaged 23 micrograms per cent.

The thiamin levels in erythrocytes of the 5 patients with acute leukemia ranged from 9 to 30 micrograms and averaged 18 micrograms per 100 ml., a value only a little less than that of all the patients studied (21 micrograms). Finally, the 3 patients whose disease was in the aleukemic state also had elevated levels of the vitamin in their red cells : 12,24 and 25 micrograms per $100 \mathrm{ml}$.

4. The concentrations of $P A Y F$ in the erythrocytes of patients with leukemia. The concentrations of PAYF were determined in the red cells of 7 of the 33 patients (Table I). These concentrations ranged from 1 to 22 micrograms and averaged 6 micrograms per cent. The PAYF thus formed from 8 per cent to 51 per cent of the total thiamin of the red cells, values which are apparently within the normal range (14.0 to 30.0 per cent).

Since the blood corpuscles of leukemic individuals contain excessive amounts of total thiamin, the results here presented would explain and confirm the observations of Sinclair (2) and of Goodhart and Sinclair (3) that leukemic patients occasionally have high concentrations of thiamin and cocarboxylase in their whole blood. It would appear that had proper corrections been made for the anemia of the blood specimens which those investigators examined, a higher incidence of abnormally high thiamin and cocarboxylase levels would have been found.

TABLE IV

Micrograms of thiamin and of PAYF* excreted per day in the urine of patients with leukemia

\begin{tabular}{|c|c|c|c|c|c|c|c|c|}
\hline $\begin{array}{l}\text { Sub- } \\
\text { ject }\end{array}$ & Weight & $\begin{array}{c}\text { Num- } \\
\text { ber } \\
\text { of } \\
\text { days }\end{array}$ & $\begin{array}{l}\text { Urinary } \\
\text { thiamin } \\
\text { range } \\
\text { per day }\end{array}$ & $\begin{array}{l}\text { Av- } \\
\text { er- } \\
\text { age } \\
\text { per } \\
\text { day }\end{array}$ & $\begin{array}{l}\text { High- } \\
\text { est } \\
\text { per } \\
\text { cent } \\
\text { daily } \\
\text { varia- } \\
\text { tion }\end{array}$ & $\begin{array}{l}\text { Urinary } \\
\text { PAYF } \\
\text { range } \\
\text { per day }\end{array}$ & $\begin{array}{l}\text { Av- } \\
\text { er- } \\
\text { age } \\
\text { per } \\
\text { day }\end{array}$ & $\begin{array}{l}\text { High- } \\
\text { est } \\
\text { per } \\
\text { cent } \\
\text { daily } \\
\text { varia- } \\
\text { tion }\end{array}$ \\
\hline $\begin{array}{l}\text { J.K. } \\
\text { P.S. } \\
\text { M.L. } \\
\text { L.J. } \\
\text { J.W. }\end{array}$ & $\begin{array}{l}\text { kilos } \\
70 \\
68 \\
60 \\
85 \\
72\end{array}$ & $\begin{array}{r}5 \\
10 \\
2 \\
4 \\
3\end{array}$ & $\begin{array}{r}238-403 \\
57-74 \\
70-83 \\
44-90 \\
65-215\end{array}$ & $\begin{array}{r}327 \\
65 \\
76 \\
78 \\
165\end{array}$ & $\begin{array}{r}69 \\
23 \\
9 \\
110 \\
230\end{array}$ & $\begin{array}{r}272-419 \\
192-243 \\
40-46 \\
55-135 \\
245-301\end{array}$ & $\begin{array}{r}360 \\
209 \\
43 \\
115 \\
256\end{array}$ & $\begin{array}{r}54 \\
26 \\
8 \\
145 \\
231\end{array}$ \\
\hline
\end{tabular}

* Expressed in thiamin equivalents.

5. The urinary excretion of total thiamin and $P A Y F$ by patients with leukemia. The excretions of thiamin and of PAYF have been determined in thirteen urine specimens of 5 adults with leukemia (Table IV). The urine collections were made over periods of from 1 to 4 days, and all of the patients had been on an adequate hospital diet without added thiamin for several days before the collections were begun. 
The excretion of true thiamin by these 5 patients ranged from 44 to 403 micrograms per day. The average daily true thiamin output of each over periods of from 2 to 10 days varied between 65 and 327 micrograms and averaged 142 micrograms. These values are similar to those of the average urinary excretion of true thiamin by each of 8 normal individuals which ranged from 83 to 350 micrograms and averaged 180 micrograms per day (1).

The excretion of PAYF in the thirteen urine specimens of the leukemic patients ranged from 40 to 419 micrograms per day, and the average daily output of each ranged from 43 to 360 micrograms. Similarly, the average urinary output of PAYF of each of 8 normal individuals varied from 194 to 556 micrograms per day, and averaged 340 micrograms per day (1). Thus the values for the urinary excretion of true thiamin and PAYF by the 5 leukemic patients were all within normal limits.

In summary, it has been found that the total thiamin levels in the white cells of 33 patients with various types of leukemia average about 3 times the normal average value, and in 85 per cent of the patients are above the highest normal. The PAYF concentration forms a smaller percentage of the total thiamin in the leukemic white cells of all patients than it does in the white cells of any normal individual studied. The average concentration of total thiamin in the erythrocytes of 33 leukemic patients also is abnormally highabout twice the normal average concentrationbut only 32 per cent of the patients studied had red cell total thiamin levels above the highest normal. In contrast to the finding in white cells, the PAYF in the erythrocytes of leukemic patients forms a normal percentage of the total thiamin. Finally, the patients with leukemia excrete normal amounts of thiamin and PAYF.

6. The concentration of total thiamin in the blood cells of patients with malignant diseases other than leukemia. It was important to determine whether or not high total thiamin concentrations were unique for the blood cells of leukemic patients. Therefore, the blood cells of groups of patients with other diseases of equal gravity were studied.

Of 8 patients with Hodgkin's disease (Table V), 6 had white cell concentrations of total thia-
TABLE V

Blood cell total thiamin in patients with Hodgkin's disease

\begin{tabular}{|c|c|c|}
\hline Patient & $\begin{array}{l}\text { White blood } \\
\text { cells }\end{array}$ & $\begin{array}{l}\text { in } \\
\text { Red blood } \\
\text { cells }\end{array}$ \\
\hline & \multicolumn{2}{|c|}{ micrograms per $100 \mathrm{ml}$. } \\
\hline $\begin{array}{l}\text { R. E.. } \\
\text { A. G.. } \\
\text { M. K. } \\
\text { P. K.. } \\
\text { R. N.. } \\
\text { L. R.. } \\
\text { J. R.. } \\
\text { F. G.. }\end{array}$ & $\begin{array}{ll}\ldots & 420 \\
\ldots & 160 \\
\ldots & 329 \\
\ldots & 274 \\
\ldots & 264 \\
\ldots & 120 \\
\ldots & 193 \\
\ldots & 187 \\
\ldots & 242\end{array}$ & $\begin{array}{r}10.2 \\
24.0 \\
19.2 \\
16.4 \\
18.0 \\
13.1 \\
10.0 \\
8.6 \\
14.0\end{array}$ \\
\hline
\end{tabular}

min above the normal range. The values varied from 120 to 420 micrograms and averaged 242 micrograms per $100 \mathrm{ml}$. of cells, or 2.5 times the normal average value. The range of the total thiamin in the red cells of this group of patients was from 8.6 to 24.0 micrograms and averaged 14.0 micrograms per $100 \mathrm{ml}$., or about 1.4 times the normal average level. It is interesting to note that this high concentration of thiamin in the blood cells of patients with Hodgkin's disease is the first indication that these cells are in any way abnormal. Furthermore, this observation suggests that a similar metabolic abnormality marks a relationship between the blood cells of patients with Hodgkin's disease and those of patients with leukemia.

Of 24 patients with cancer of the gastro-intestinal tract, the white cell concentrations of total thiamin ranged from 33 to 400 micrograms per cent, and the average was 179 micrograms per cent, or about twice the normal average value (Table VI). Of the 24 patients, 11 , or 46 per cent, had white cell thiamin levels above the highest normal value. The erythrocyte thiamin levels of 15 of these 24 patients also were determined. These ranged from 4 to 24 micrograms and averaged 14 micrograms per $100 \mathrm{ml}$. Only 1 of the 15 individuals had an erythrocyte thiamin level above the normal range.

Of 5 patients with cirrhosis of the liver (Table VII), the white cell concentrations of total thiamin in 3 were within normal limits, and in the other 2 somewhat below the normal range. These concentrations varied from 27 to 175 micrograms and averaged 98 micrograms per $100 \mathrm{ml}$. The red cell total thiamin was determined in 4 of these 5 
TABLE VI

Blood cell total thiamin in patients with cancer of the gastro-intestinal tract

\begin{tabular}{|c|c|c|}
\hline Patien & $\begin{array}{l}\text { Tot: } \\
\text { White blood } \\
\text { cells }\end{array}$ & $\begin{array}{l}\text { Red blood } \\
\text { cells }\end{array}$ \\
\hline $\begin{array}{l}\text { R. M. } \\
\text { L. B. } \\
\text { K. B. } \\
\text { E. B. } \\
\text { F. F.. } \\
\text { F. M. } \\
\text { R. K. } \\
\text { M. M } \\
\text { I. C.. } \\
\text { M. P. } \\
\text { J. P.. } \\
\text { F. P. } \\
\text { J. S.. } \\
\text { O. S. } \\
\text { F. W. } \\
\text { R. L. } \\
\text { A. S. } \\
\text { O. J.. } \\
\text { S. K. } \\
\text { L. L. } \\
\text { G. B. } \\
\text { J. W. } \\
\text { F. C. } \\
\text { S. T. }\end{array}$ & \begin{tabular}{lr} 
& \multicolumn{1}{c}{ microgra } \\
$\ldots$ & 164 \\
$\ldots$ & 231 \\
$\ldots$ & 128 \\
$\ldots$ & 115 \\
$\ldots$ & 284 \\
$\ldots$ & 226 \\
$\ldots$ & 321 \\
$\ldots$ & 400 \\
$\ldots$ & 58 \\
$\ldots$ & 51 \\
$\ldots$ & 292 \\
$\ldots$ & 274 \\
$\ldots$ & 33 \\
$\ldots$ & 214 \\
$\ldots$ & 110 \\
$\ldots$ & 202 \\
$\ldots$ & 168 \\
$\ldots$ & 100 \\
$\ldots$ & 80 \\
$\ldots$ & 210 \\
$\ldots$ & 236 \\
$\ldots$ & 131 \\
$\ldots$ & 115 \\
$\ldots$ & 141 \\
$\ldots$ & 179
\end{tabular} & $\begin{array}{r}100 \mathrm{ml} . \\
11 \\
16 \\
13 \\
18 \\
17 \\
24 \\
18 \\
16 \\
12 \\
19 \\
13 \\
\\
4 \\
8 \\
13 \\
6\end{array}$ \\
\hline
\end{tabular}

patients and ranged from 1.7 to 16.5 micrograms per cent and averaged 7.6 micrograms per cent.

It would appear, therefore, that elevated blood cell concentrations of total thiamin are not specific for patients with leukemia, but are to be found also in the morphologically normal blood cells of patients with other neoplastic growths. This fact also indicates that the high thiamin levels in leukemic leukocytes and platelets are not due to the immaturity of the cells concerned.

TABLE VII

Blood cell total thiamin in patients with cirrhosis of liver

\begin{tabular}{|c|c|c|}
\hline Patient & $\begin{array}{l}\text { White blood } \\
\text { cells }\end{array}$ & $\begin{array}{l}\text { Red blood } \\
\text { cells }\end{array}$ \\
\hline $\begin{array}{l}\text { M. R. } \\
\text { H. R. } \\
\text { M. S. } \\
\text { I. T. } \\
\text { H. H. }\end{array}$ & $\begin{array}{lr} & \text { microgra } \\
\ldots & 27 \\
\ldots & 153 \\
\ldots & 94 \\
\ldots & 175 \\
\ldots & 35\end{array}$ & $\begin{array}{r}100 \mathrm{ml} . \\
1.7 \\
16.5 \\
7.1 \\
5.2\end{array}$ \\
\hline
\end{tabular}

B. Experiments to determine the cause of the high concentrations of thiamin in the blood cells of patients with leukemia

The most probable explanations of the high concentrations of total thiamin in the blood cells of patients with leukemia are that the patients had (1) a high dietary intake of thiamin, (2) white cells, which because of their youth, have an accelerated rate of normal metabolism, (3) impaired utilization of the vitamin, or (4) faulty excretion of the vitamin.

1. Were the high thiamin levels of leukemic white cells due to excessive ingestion of thiamin? Since it has been demonstrated in the previous communication (1) that the daily intake of from $10 \mathrm{mgm}$. to $100 \mathrm{mgm}$. of thiamin for from 3 to 7 days can elevate the white cell content of the vitamin to the range found in leukemic leukocytes and platelets, it was necessary to determine whether or not the leukemic patients had ingested excessive amounts of thiamin. When the dietary histories of the patients were examined, none indicated that any supplements of thiamin or of thiamin-rich extracts had been taken for at least 3 weeks before admission to the hospital. It is therefore impossible to attribute the occurrence of high concentrations of blood cell thiamin to an abnormally high intake of the vitamin.

2. Were the high thiamin levels of leukemic white cells a function of their youth and consequently accelerated rate of normal metabolism? The frequent occurrence of high levels of thiamin in leukemic white cells suggested that such elevations were due to the comparative youth of the cell types affected. From observations already presented this explanation appeared to be untenable. It has been pointed out that:

$a$. No significant difference was found between the concentrations of total thiamin in the white cells of patients with acute leukemia and of patients with aleukemic leukemia, although the white cells of the latter group were much more mature than those of the former.

$b$. The concentrations of total thiamin were elevated in the white cells of 75 per cent of patients with Hodgkin's disease, and of 46 per cent of patients with cancer of the gastro-intestinal tract. These white cells apparently were morphologically mature.

c. Abnormally elevated concentrations of total thiamin were found in the red cells of the patients with leukemia. There was no reason to believe that those cells were any younger than the erythrocytes normally found in healthy individuals. 
Despite this evidence it was desirable to study further the possibility that the thiamin concentration of cells was a function of their age and development, and that higher concentrations existed in the younger cells. If it could be demonstrated, however, that the thiamin levels in normal myelocytes or erythroblasts were not significantly higher than those in the mature white cells of the peripheral blood, such a hypothesis could be ruled out.

Accordingly, two suspensions of rabbit myelocytes and two of erythroblasts were made by the methods of Warren (5) from the white and red marrow, respectively. Three suspensions of mature white cells from whole blood were prepared by the techniques already described. Determinations of the total thiamin levels of all of these suspensions revealed no significant differences, and all the levels were within the range of those found in normal mature white cells (Table VIII).

\section{TABLE VIII}

The total thiamin in the marrow myelocytes, marrow erythroblasts, peripheral white cells, and peritoneal white cells of rabbits

\begin{tabular}{l|c|c|c|c}
\hline \hline & \multicolumn{4}{|c}{ Total thiamin } \\
\cline { 2 - 5 } & $\begin{array}{c}\text { Peripheral } \\
\text { white cells }\end{array}$ & $\begin{array}{c}\text { Marrow } \\
\text { myelo- } \\
\text { cytes }\end{array}$ & $\begin{array}{c}\text { Marrow } \\
\text { erythro- } \\
\text { blasts }\end{array}$ & $\begin{array}{c}\text { Peritoneal } \\
\text { white cells }\end{array}$ \\
\hline Rabbit number 1 & 100 & 171 & & 328 \\
Rabbit number 2 & 80 & 99 & & 300 \\
Rabbit number 3 & 137 & & 87.5 & \\
Rabbit number 4 & & & 140 & \\
\hline
\end{tabular}

The total thiamin concentrations of the three preparations of mature white cells from rabbit blood were 80,100 , and 137 micrograms per cent ; those of the erythroblasts 88 and 140 micrograms per cent, and those of the myeloblasts 99 and 171 micrograms per cent. Since the immature nucleated marrow cells did not have the abnormally high concentrations of the vitamin such as were found in leukemic white cells, the possibility was excluded that the high thiamin content of leukemic leukocytes and platelets reflected only their comparative youth.
A second approach to this problem was attempted. By the repeated injection of saline into the peritoneal cavity of a rabbit, and the withdrawal of the fluid 8 hours later, it is possible to recover progressively younger leukocytes in each successive exudate (6). In this manner two suspensions of polymorphonuclear cells and one of metamyelocytes were obtained for a comparison of their concentrations of intracellular thiamin. The measurement of the vitamin in these suspensions thus would reveal whether or not higher concentrations of thiamin existed in younger cells.

It was found, however, that the two suspensions of adult polymorphonuclear cells had thiamin levels of 328 and 307 micrograms per $100 \mathrm{ml}$., whereas the subsequently formed metamyelocytes had a thiamin concentration of 300 and 206 micrograms per $100 \mathrm{ml}$. Therefore, it appears that not only do the younger metamyelocytes have less thiamin than do the adult polynuclears, but both cell types obtained from the exudates have concentrations of the vitamin considerably higher than those in the adult white cells of the peripheral blood, or in the immature marrow cells. It is possible that this discrepancy might be due to the fact that the exudate cells, by the nature of their formation, are injured cells, and thus are not comparable to peripheral or marrow blood cells.

From the evidence at hand, however, it would appear that the concentration of thiamin in the white cells is not a function of the age or development of those cells. Therefore, some other explanation must be sought to explain the high levels of thiamin in leukemic leukocytes.

3. Were the high blood cell thiamin levels due to an impaired utilization of the vitamin by the cells? In the communication previously referred to (1), a method was described for the study of the relationship between thiamin and PAYF in the normal blood cells and urine. It appeared from the evidence that thiamin, during its normal physiologic activity, probably is converted in the normal white cells to the PAYF compound. This conclusion was based on the observation that the intravenous administration of thiamin to normal individuals was followed consistently by an immediate and significant increase in the concentrations of thiamin and PAYF in both the white cells and urine. 
In section $A .1$. of this study, it was shown that not only were the concentrations of blood cell total thiamin abnormally high in the leukemic patients, but also that the PAYF content of the leukocytes and platelets formed a much smaller percentage of the blood cell content of total thiamin than it did in normal white cells. This discrepancy suggested, therefore, that in the leukemic white blood cells the rate or degree of formation of PAYF from the vitamin was decreased.

In order to test that possibility further, it was necessary to study in leukemics the effects of the intravenous administration of thiamin and its probable normal metabolite, the PAYF compound, on the contents of those substances in the blood and urine. Six patients with chronic leukemia-3 females and 3 males, 5 with myeloid and 1 with lymphoid disease-were used for this study. The experiments were done under the same conditions, and in the same manner as described in the preceding paper (1). Five of the 6 patients received both the thiamin and, several days later, 2 - methyl-5-methoxyethyl-6-amino-pyrimidine. One patient received only the intravenous injection of the thiamin.

The results obtained after the administration of the test substances to the leukemic individuals were in sharp contrast to those observed in normal controls. The intravenous administration of $5 \mathrm{mgm}$. of thiamin to each of the 5 normal adults had been followed by a rise within the first 3 hours of the white cell thiamin from 80 per cent to 132 per cent, and the average rise was 100 per cent. Likewise, there followed a rise in the white cell PAYF of each individual from 41 per cent to 173 per cent, and the average rise was 143 per cent. In the 6 leukemic patients, on the other hand, the administration of $5 \mathrm{mgm}$. of thiamin intravenously was followed in every instance by a fall in the white cell concentrations of thiamin, and in 4 of the 6 by a fall in the PAYF as well (Table IX) (Figure 3). The thiamin concentration decreased within the first 3 hours after the injection by from 4 per cent to 59 per cent, and the average

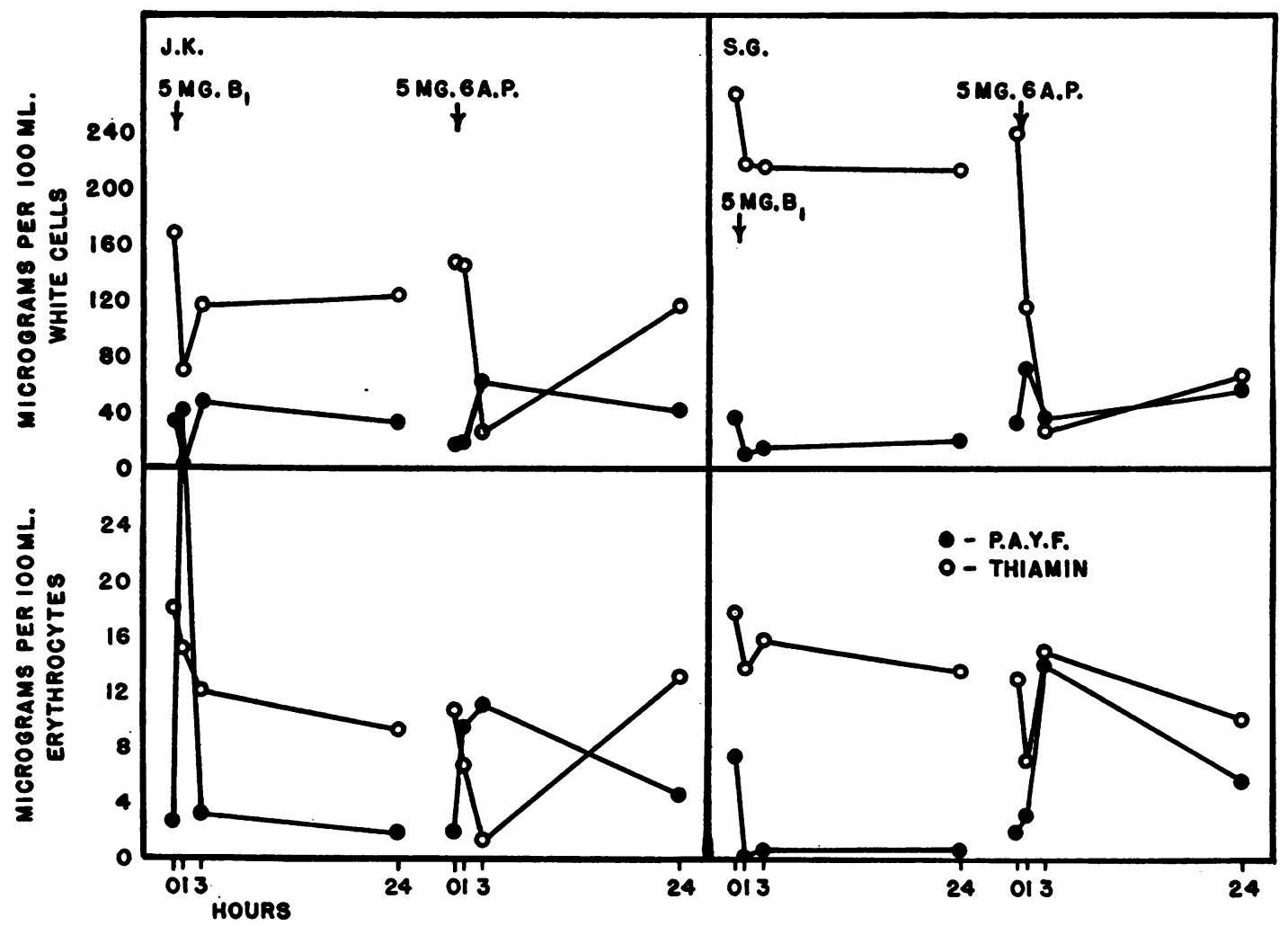

Fig. 3. The Levels of Thiamin and of PAYF in White Cells and Erythrocytes of Patients with Leukemia after the Intravenous administration of 5 Mgm. of Thiamin and 5 Mgm. of 2-Methyl-5-Methoxyethyl-6-Amino Pyrimidine 
decrease was 32 per cent. The PAYF of the leukemic white cells of the 4 patients decreased by from 36 per cent to 72 per cent in the first 3 hours, and the average decrease was 60 per cent.

TABLE IX

The concentrations of true thiamin and of $P A Y F^{*}$ in the white cells and erythrocytes of patients with leukemia given thiamin and 2-methyl-5-methoxyethyl-6-amino-pyrimidine

\begin{tabular}{|c|c|c|c|c|c|c|}
\hline \multirow{2}{*}{ Patient } & \multirow{2}{*}{ Given } & \multirow{2}{*}{$\begin{array}{l}\text { Hours } \\
\text { after } \\
\text { injec- } \\
\text { tion }\end{array}$} & \multicolumn{2}{|c|}{ White blood cells } & \multicolumn{2}{|c|}{ Red blood cells } \\
\hline & & & $\begin{array}{c}\text { True } \\
\text { thiamin }\end{array}$ & PAYF & $\begin{array}{c}\text { True } \\
\text { thiamin }\end{array}$ & PAYF \\
\hline & & & $\begin{array}{l}\text { micro } \\
\text { per } 10\end{array}$ & ams & $\begin{array}{l}\text { micro } \\
\text { per } 1 C\end{array}$ & $\begin{array}{l}\text { ams } \\
\text { ml. }\end{array}$ \\
\hline \multirow[t]{2}{*}{ S. G. } & $\begin{array}{c}5 \text { mgm. } \\
\mathrm{B}_{1}\end{array}$ & $\begin{array}{r}0 \\
1 \\
3 \\
24\end{array}$ & $\begin{array}{l}266 \\
216 \\
213 \\
212\end{array}$ & $\begin{array}{l}36 \\
10 \\
15 \\
16\end{array}$ & $\begin{array}{l}17.7 \\
13.7 \\
15.8 \\
13.6\end{array}$ & $\begin{array}{l}7.3 \\
0 \\
0.6 \\
0.5\end{array}$ \\
\hline & $5 \underset{6 A P}{\mathrm{mgm}}$ & $\begin{array}{r}0 \\
1 \\
3 \\
24\end{array}$ & $\begin{array}{r}238 \\
115 \\
27 \\
66\end{array}$ & $\begin{array}{l}33 \\
70 \\
36 \\
56\end{array}$ & $\begin{array}{r}13 \\
7 \\
15 \\
10\end{array}$ & $\begin{array}{c}1.9 \\
3.1 \\
14 \\
5.5\end{array}$ \\
\hline \multirow[t]{2}{*}{ M. K. } & $5 \underset{B_{1}}{\mathrm{mgm}}$ & $\begin{array}{r}0 \\
1 \\
3 \\
24\end{array}$ & $\begin{array}{l}221 \\
212 \\
223 \\
229\end{array}$ & $\begin{array}{r}10.7 \\
11.2 \\
6.9 \\
10.9\end{array}$ & $\begin{array}{r}9.4 \\
10.4 \\
9.7 \\
6.5\end{array}$ & $\begin{array}{l}0 \\
2.0 \\
2.1 \\
1.2\end{array}$ \\
\hline & $5 \underset{6 A P}{\mathrm{mgm}}$ & $\begin{array}{r}0 \\
1 \\
3 \\
24\end{array}$ & $\begin{array}{l}183 \\
171 \\
218 \\
211\end{array}$ & $\begin{array}{l}23.7 \\
21.6 \\
43.0 \\
11.0\end{array}$ & $\begin{array}{r}8.2 \\
9.3 \\
10.1 \\
6.1\end{array}$ & $\begin{array}{l}1.7 \\
8.7 \\
4.4 \\
0.5\end{array}$ \\
\hline \multirow[t]{2}{*}{ J. K. } & $5 \underset{B_{1}}{\text { mgm. }}$ & $\begin{array}{r}0 \\
1 \\
3 \\
24\end{array}$ & $\begin{array}{r}167 \\
69 \\
116 \\
123\end{array}$ & $\begin{array}{r}33 \\
2.4 \\
47.5 \\
33.5\end{array}$ & $\begin{array}{r}18 \\
15.2 \\
12.0 \\
9.2\end{array}$ & $\begin{array}{r}2.5 \\
32.0 \\
3.1 \\
1.7\end{array}$ \\
\hline & $5 \underset{6 A P}{\mathrm{mgm}}$ & $\begin{array}{r}0 \\
1 \\
3 \\
24\end{array}$ & $\begin{array}{c}146 \\
144 \\
26.3 \\
116\end{array}$ & $\begin{array}{l}17.5 \\
18.3 \\
61.7 \\
40.4\end{array}$ & $\begin{array}{r}10.6 \\
6.1 \\
13.1\end{array}$ & $\begin{array}{l}1.8 \\
9.5 \\
4.5\end{array}$ \\
\hline \multirow[t]{2}{*}{ L. J. } & $5 \underset{\mathrm{B}_{1}}{\mathrm{mgm}}$ & $\begin{array}{r}0 \\
1 \\
3 \\
24\end{array}$ & $\begin{array}{l}226 \\
142 \\
113 \\
320\end{array}$ & $\begin{array}{r}3.8 \\
9.0 \\
41.0 \\
20.0\end{array}$ & $\begin{array}{r}7.4 \\
14.4 \\
3.9 \\
8.0\end{array}$ & $\begin{array}{r}1.6 \\
1.6 \\
6.1 \\
13.0\end{array}$ \\
\hline & $5 \underset{6 A P}{\operatorname{mgm}}$ & $\begin{array}{r}0 \\
1 \\
3 \\
24\end{array}$ & $\begin{array}{r}371 \\
253 \\
201 \\
94\end{array}$ & $\begin{array}{r}20 \\
104 \\
79 \\
143\end{array}$ & $\begin{array}{l}7 \\
35 \\
17.4 \\
10.2\end{array}$ & $\begin{array}{c}14 \\
1 \\
2.6 \\
8.0\end{array}$ \\
\hline A. M. & $5 \underset{\mathrm{B}_{1}}{\mathrm{mgm}}$ & $\begin{array}{r}0 \\
1 \\
3 \\
24\end{array}$ & $\begin{array}{l}246 \\
157 \\
222 \\
285\end{array}$ & $\begin{array}{r}10 \\
12.9 \\
4.4 \\
21.4\end{array}$ & $\begin{array}{r}11.9 \\
9.9 \\
3.3 \\
11.8\end{array}$ & $\begin{array}{l}1.0 \\
0.9 \\
7.4 \\
2.1\end{array}$ \\
\hline \multirow[t]{2}{*}{ J. W. } & $5 \underset{\mathrm{B}_{1}}{\mathrm{mgm}}$ & $\begin{array}{r}0 \\
1 \\
3 \\
24\end{array}$ & $\begin{array}{l}493 \\
353 \\
423 \\
462\end{array}$ & $\begin{array}{l}10 \\
9.4 \\
11.5 \\
61\end{array}$ & $\begin{array}{l}40 \\
18 \\
18 \\
11\end{array}$ & $\begin{array}{r}1.0 \\
5.0 \\
4.0 \\
20.0\end{array}$ \\
\hline & $5 \underset{6 A P}{\text { mgm. }}$ & $\begin{array}{r}0 \\
1 \\
3 \\
24\end{array}$ & $\begin{array}{l}569 \\
600 \\
369 \\
634\end{array}$ & $\begin{array}{l}31 \\
65.4 \\
84.0 \\
11.0\end{array}$ & $\begin{array}{c}20.4 \\
18 \\
18 \\
6\end{array}$ & $\begin{array}{l}21.6 \\
22 \\
19 \\
34\end{array}$ \\
\hline
\end{tabular}

In the other 2 of the 6 patients, the administration of thiamin was followed by a rise in the white cell content of PAYF of from 4 to 41 micrograms per cent (L. W.) and from 10 to 60 micrograms per cent (J. W.).

Although the administration of $5 \mathrm{mgm} .^{3}$ of 2 methyl-5-methoxyethyl-6-amino-pyrimidine to 5 normal individuals was followed in every instance by a rise in the white cell content of PAYF, it was not followed by any rise in the white cell thiamin in 3 of the 5 individuals. In the white cells of 5 leukemic patients to whom $5 \mathrm{mgm}$. of 2-methyl-5methoxyethyl-6-amino-pyrimidine were administered intravenously, the content of PAYF rose in all by from 100 per cent to 420 per cent. The average rise was 249 per cent. It is interesting to note, however, that the injection was followed consistently within the first 3 hours by a fall in white cell thiamin. This fall ranged from 6.5 per cent to 82.0 per cent.

Thus it seems that some deviation from the normal handling of administered thiamin exists in the leukemic leukocytes and platelets. The evidence which indicates such an aberration is as follows: (1) Under fasting conditions PAYF, a probable normal metabolite of thiamin, formed an abnormally small percentage of the total thiamin content. (2) The intravenous administration of the thiamin to leukemic patients was always followed by a fall, and not a rise, in the white cell concentration of thiamin. (3) The administration of the thiamin was followed by a fall, and not a rise, in the PAYF content in the white cells of 4 of 6 of the patients. In the leukemic, as in the normal, white blood cells there is no reason to believe that thiamin is formed from administered pyrimidine.

Similar measurements were made in the erythrocytes of the patients with leukemia who had received thiamin and 2-methyl-5-methoxyethyl-6amino-pyrimidine. As in the previous study of normal individuals, no consistent results were obtained. Only the results of the administration of the test substances to the leukemic patients are shown in Table IX and Figure 3 and no attempt has been made to draw any conclusions from them.

The existence of an abnormal metabolism of thiamin in the patient with leukemia is supported to some degree by the results of experiments in

\footnotetext{
${ }^{3}$ Equivalent to $10.7 \mathrm{mgm}$. of thiamin in yeast-stimulating activity.
} 
which measurements of the urinary concentrations of thiamin and pyrimidine were made after the injection of those substances. These experiments, too, were performed exactly as described in the previous communication (1).

In the 8 normal individuals used for the previous study, it was demonstrated that the intravenous administration of $5 \mathrm{mgm}$. of thiamin in every instance was followed during the next 24 hours by a significant increase in the urinary excretion of both thiamin (from 121 to 835 per cent of the average control level) and PAYF (from 89 to 428 per cent of the average control level). On the other hand, no significantly increased excretion of thiamin occurred during the administration of either 2-methyl-5-methoxyethyl-6-aminopyrimidine or the pyrimidine formed by the alkaline cleavage of the vitamin itself. These observations thus lent further support to the hypothesis that in normal individuals thiamin is converted to the pyrimidine compound.

TABLE $X$

Micrograms of thiamin excreted per day in the urine of patients with leukemia before and after the intravenous injection of thiamin

\begin{tabular}{|c|c|c|c|c|c|c|c|}
\hline \multirow{3}{*}{ Patient } & \multirow{3}{*}{$\begin{array}{c}\text { Num- } \\
\text { of } \\
\text { days }\end{array}$} & \multicolumn{3}{|c|}{ Control period } & \multicolumn{3}{|c|}{ After injection } \\
\hline & & \multirow{2}{*}{$\begin{array}{c}\text { Urinary } \\
\text { thiamin } \\
\text { range } \\
\text { per day }\end{array}$} & \multirow{2}{*}{$\begin{array}{l}\text { Aver- } \\
\text { age } \\
\text { per } \\
\text { day }\end{array}$} & \multirow{2}{*}{$\begin{array}{c}\text { High- } \\
\text { est } \\
\text { per } \\
\text { cent } \\
\text { daily } \\
\text { varia- } \\
\text { tion }\end{array}$} & \multirow{2}{*}{$\begin{array}{l}24- \\
\text { hour } \\
\text { out- } \\
\text { put }\end{array}$} & \multicolumn{2}{|c|}{$\begin{array}{c}\text { Per cent } \\
\text { increase over }\end{array}$} \\
\hline & & & & & & $\begin{array}{l}\text { Pre- } \\
\text { vious } \\
\text { day }\end{array}$ & $\begin{array}{l}\text { Aver- } \\
\text { age } \\
\text { con- } \\
\text { trol } \\
\text { day }\end{array}$ \\
\hline $\begin{array}{l}\text { J. K. } \\
\dot{\mathrm{M}} . \mathrm{K} . \\
\text { L. J. } \\
\text { J. W. }\end{array}$ & $\begin{array}{l}5 \\
2 \\
4 \\
3\end{array}$ & $\begin{array}{r}238-403 \\
70-83 \\
44-90 \\
65-215\end{array}$ & $\begin{array}{r}327 \\
76 \\
78 \\
165\end{array}$ & $\begin{array}{r}69 \\
9 \\
110 \\
230\end{array}$ & $\begin{array}{r}1263 \\
722 \\
1146 \\
326\end{array}$ & $\begin{array}{r}430 \\
720 \\
3200 \\
310\end{array}$ & $\begin{array}{r}278 \\
850 \\
950 \\
98\end{array}$ \\
\hline
\end{tabular}

In sharp contrast to these findings are the results of a similar study of leukemic individuals. Five mgm. of thiamin were administered to each of 4 patients with chronic leukemia-2 females and 2 males, 3 with myeloid and 1 with lymphoid disease. In all 4, the administration of the thiamin increased the urinary excretion of the vitamin during the next 24-hour period by from 30 per cent to 3200 per cent (Table X). These increases are significantly higher than those which the injection of the same amount of thiamin affected in the normal controls (121 to 835 per cent).
The leukemic patients excreted only a little less pyrimidine after the injection of thiamin than did the normals. In all 8 normals the injection of 5 mgm. of the vitamin had resulted in increased urinary output of PAYF which ranged from 89 per

TABLE XI

Micrograms of PAYF* excreted per day in the urine 0 , patients with leukemia before and after the intravenous injection of thiamin

\begin{tabular}{|c|c|c|c|c|c|c|c|}
\hline \multirow{3}{*}{ Patient } & \multirow{3}{*}{$\begin{array}{c}\text { Num- } \\
\text { ber } \\
\text { of } \\
\text { days }\end{array}$} & \multicolumn{3}{|c|}{ Control period } & \multicolumn{3}{|c|}{ After injection } \\
\hline & & \multirow{2}{*}{$\begin{array}{c}\text { Urinary } \\
\text { PAYF } \\
\text { range } \\
\text { per day }\end{array}$} & \multirow{2}{*}{$\begin{array}{l}\text { Aver- } \\
\text { age } \\
\text { per } \\
\text { day }\end{array}$} & \multirow{2}{*}{$\begin{array}{l}\text { High- } \\
\text { est } \\
\text { per } \\
\text { cent } \\
\text { daily } \\
\text { varia- } \\
\text { tion }\end{array}$} & \multirow{2}{*}{$\begin{array}{l}\text { 24- } \\
\text { hour } \\
\text { out- } \\
\text { put }\end{array}$} & \multicolumn{2}{|c|}{$\begin{array}{c}\text { Per cent } \\
\text { increase over }\end{array}$} \\
\hline & & & & & & $\begin{array}{c}\text { Pre- } \\
\text { vious } \\
\text { day }\end{array}$ & $\begin{array}{l}\text { Aver- } \\
\text { age } \\
\text { con- } \\
\text { trol } \\
\text { day }\end{array}$ \\
\hline & $\begin{array}{l}5 \\
2 \\
4 \\
3\end{array}$ & $\begin{array}{r}272-419 \\
40-46 \\
55-135 \\
245-301\end{array}$ & $\begin{array}{r}360 \\
43 \\
115 \\
256\end{array}$ & $\begin{array}{r}54 \\
8 \\
145 \\
231\end{array}$ & $\begin{array}{l}448 \\
214 \\
199 \\
519\end{array}$ & $\begin{array}{c}70 \\
366 \\
261 \\
71.5\end{array}$ & $\begin{array}{c}24.5 \\
394 \\
73 \\
104\end{array}$ \\
\hline
\end{tabular}

* Expressed in thiamin equivalents.

cent to 428 per cent, and averaged 189 per cent above their average output. In the 4 leukemic patients, the changes in the urinary excretion of that substance during the succeeding day ranged from 24 to 394 per cent above the average output, and averaged 143 per cent (Table XI).

The 4 patients also received intravenously 5 mgm. ${ }^{4}$ of 2-methyl-5-methoxyethyl-6-amino-pyrimidine. The results of this experiment were, in general, the same as those in which the compound was administered to normal individuals. The injection produced during the next 24 hours an increased output of thiamin (128 per cent) in only 1 patient, and an increased output of PAYF (by from 102 to 1105 per cent) in all (Tables $\mathrm{XII}$ and XIII).

From these measurements of urinary thiamin and PAYF it would appear that the leukemic patient utilized less of the administered vitamin than did the normal individual.

4. Were the high blood cell thiamin levels due to faulty excretion of the vitamin? It is obvious that should any interference in the excretion of thiamin exist in patients with leukemia, a cause for the high levels of the vitamin in the blood

4 Equivalent to $10.7 \mathrm{mgm}$. of thiamin in yeast-stimulating activity. 
TABLE XII

Micrograms of PAYF* excreted per day in the urine of patients with leukemia before and after the intravenous injection of 2-methyl-5-methoxyethyl-6-amino-pyrimidine

\begin{tabular}{|c|c|c|c|c|c|c|c|}
\hline \multirow{3}{*}{ Patient } & \multirow{3}{*}{$\begin{array}{c}\text { Num- } \\
\text { ber } \\
\text { of } \\
\text { days }\end{array}$} & \multicolumn{3}{|c|}{ Control period } & \multicolumn{3}{|c|}{ After injection } \\
\hline & & \multirow{2}{*}{$\begin{array}{c}\text { Urinary } \\
\text { PAYF } \\
\text { range } \\
\text { per day }\end{array}$} & \multirow{2}{*}{$\begin{array}{c}\text { Aver- } \\
\text { age } \\
\text { per } \\
\text { day }\end{array}$} & \multirow{2}{*}{$\begin{array}{l}\text { High- } \\
\text { est } \\
\text { per } \\
\text { cent } \\
\text { daily } \\
\text { varia- } \\
\text { tion }\end{array}$} & \multirow{2}{*}{$\begin{array}{l}\text { 24- } \\
\text { hour } \\
\text { out- } \\
\text { put }\end{array}$} & \multicolumn{2}{|c|}{$\begin{array}{c}\text { Per cent } \\
\text { increase over }\end{array}$} \\
\hline & & & & & & $\begin{array}{l}\text { Pre- } \\
\text { vious } \\
\text { day }\end{array}$ & $\begin{array}{l}\text { Aver- } \\
\text { age } \\
\text { con- } \\
\text { trol } \\
\text { day }\end{array}$ \\
\hline $\begin{array}{l}\text { J. K. } \\
\dot{\mathrm{M}} \cdot \dot{\mathrm{K}} . \\
\text { L. J. } \\
\text { J. W. }\end{array}$ & $\begin{array}{l}5 \\
2 \\
4 \\
3\end{array}$ & $\begin{array}{r}272-419 \\
40-46 \\
55-135 \\
245-301\end{array}$ & $\begin{array}{r}360 \\
43 \\
115 \\
256\end{array}$ & $\begin{array}{r}54 \\
8 \\
145 \\
231\end{array}$ & $\begin{array}{r}730 \\
536 \\
327 \\
1152\end{array}$ & $\begin{array}{r}154 \\
1006 \\
23 \\
368\end{array}$ & $\begin{array}{r}102 \\
1105 \\
185 \\
350\end{array}$ \\
\hline
\end{tabular}

* Expressed in thiamin equivalents.

TABLE XIII

Micrograms of thiamin excreted per day in the urine of patients with leukemia before and after the intravenous injection of 2-methyl-5-methoxyethyl-6-amino-pyrimidine

\begin{tabular}{|c|c|c|c|c|c|c|c|}
\hline \multirow{3}{*}{ Patient } & \multirow{3}{*}{$\begin{array}{c}\text { Num- } \\
\text { of } \\
\text { days }\end{array}$} & \multicolumn{3}{|c|}{ Control period } & \multicolumn{3}{|c|}{ After injection } \\
\hline & & \multirow{2}{*}{$\begin{array}{c}\text { Urinary } \\
\text { thiamin } \\
\text { range } \\
\text { per day }\end{array}$} & \multirow{2}{*}{$\begin{array}{l}\text { Aver- } \\
\text { age } \\
\text { per } \\
\text { day }\end{array}$} & \multirow{2}{*}{$\begin{array}{c}\text { High- } \\
\text { est } \\
\text { per } \\
\text { cent } \\
\text { daily } \\
\text { varia- } \\
\text { tion }\end{array}$} & \multirow{2}{*}{$\begin{array}{c}\text { 24- } \\
\text { hour } \\
\text { out- } \\
\text { put }\end{array}$} & \multicolumn{2}{|c|}{$\begin{array}{c}\text { Per cent } \\
\text { increase over }\end{array}$} \\
\hline & & & & & & $\begin{array}{l}\text { Pre- } \\
\text { vious } \\
\text { day }\end{array}$ & $\begin{array}{l}\text { Aver- } \\
\text { age } \\
\text { con- } \\
\text { trol } \\
\text { day }\end{array}$ \\
\hline & $\begin{array}{l}5 \\
2 \\
4 \\
3\end{array}$ & $\begin{array}{r}238-403 \\
70-83 \\
44-90 \\
65-215\end{array}$ & $\begin{array}{r}327 \\
76 \\
78 \\
165\end{array}$ & $\begin{array}{r}69 \\
9 \\
110 \\
230\end{array}$ & $\begin{array}{r}164 \\
74 \\
178 \\
170\end{array}$ & $\begin{array}{l}59 \\
12 \\
96 \\
26\end{array}$ & $\begin{array}{r}-100 \\
3 \\
128 \\
3\end{array}$ \\
\hline
\end{tabular}

cells would be at hand. From the results obtained in the previous section $(B .2$.) of this communication, however, it is apparent that no retention of the vitamin exists. The leukemic patients excreted under normal conditions as much thiamin and PAYF as did the normal individuals.

\section{DISCUSSION}

It has been demonstrated in this investigation that leukemic blood cells are physiologically abnormal in their content and utilization of thiamin. This abnormality of leukemic cells is not the first which has been noted. Victor and Wintersteiner (7) found that both the aerobic and anaerobic glycolysis of leukemic leukocytes of mice were considerably higher than those of normal mice, but that no significant difference existed in the total respiratory activities $\left(\mathrm{QO}_{2}\right)$ of those cells.
Furthermore, when leukemic leukocytes are injected into normal mice, the leukocytes of the host also develop abnormal rates of carbohydrate metabolism before any morphological changes are recognizable (8). It also has been found that the blood of patients with leukemia has abnormal concentrations of substances concerned with enzyme systems, namely: choline esterase (9) and Coenzymes I and II (10). More recently, Butler and Cushman (4) have shown that the concentration of vitamin $\mathrm{C}$ in leukemic leukocytes and platelets was 10 times that of normal leukocytes and platelets.

From the results of the experiments presented, it appears that leukemic white cells no longer metabolize thiamin in the normal manner. This abnormality is a limitation in the conversion of the vitamin to the PAYF compound. The evidence for such a conclusion is (1) the PAYF of leukemic leukocytes and platelets forms an abnormally small percentage of the total thiamin present and (2) the administration of thiamin intravenously to 6 patients with the disorder always was followed by a decrease in the concentration of white cell thiamin; in 4 of 6 instances it was followed by a decreased concentration of PAYF and by urinary excretions of the vitamin significantly higher than those which followed the administration of an equal quantity of thiamin to normal individuals.

At present there is no apparent explanation for the limitation of thiamin conversion to PAYF and of the consequent accumulation of the intracellular vitamin. It has been accepted that the vitamin, in the form of a pyrophosphate, functions in a carboxylase enzyme system as a coenzyme (cocarboxylase). Thus a reasonable suggestion for its non-utilization by leukemic cells would be that in these cells (1) thiamin did not form the pyrophosphate ester or (2) the pyrophosphate was formed but was not used because of some inactivation of the enzyme itself.

Measurements of cocarboxylase in the whole blood of patients with leukemia have been made by Goodhart and Sinclair (3). Despite the fact that the patients studied were anemic, the concentration of cocarboxylase in their blood was found to be either within normal limits or elevated. Thus it would appear that there was no defect in the formation of cocarboxylase. 
If it could be demonstrated that leukemic leukocytes were deficient in a carboxylase, or that the form in which that enzyme was present was altered, an explanation for the accumulation of thiamin or its pyrophosphate, cocarboxylase, would be at hand. To ascertain the facts concerning this question, it is necessary to devise methods for the quantitative estimation of a carboxylase in the white cells, and an attempt to do so is now under way in this laboratory.

Since the patient with leukemia does excrete normal amounts of PAYF in his urine, and in the same ratio to free thiamin as does the normal individual, it would appear that thiamin probably does undergo normal metabolic degradation elsewhere than in the blood cells. Furthermore, the metabolism of the vitamin in the leukocytes and platelets probably contributes but little to the total formation and urinary excretion of its breakdown product. The abnormal thiamin metabolism found in leukemic white cells probably does not exist to the same extent, or at all, in the other tissues of the patient.

\section{CONCLUSIONS}

1. The total thiamin levels in the leukocytes and platelets of patients with leukemia are about 3 times the normal average value, and in 82 per cent of the patients they are above the highest normal. The concentration of PAYF in the leukemic leukocytes and platelets forms an abnormally small percentage of the total thiamin content.

2. The total thiamin levels in the erythrocytes of leukemic patients are about twice the normal average level, and are above the highest normal range in 35 per cent of the patients examined. In the erythrocytes, however, the concentrations of PAYF formed a normal percentage of the total thiamin.

3. No obvious correlation was found to exist between the concentration of blood cell total thia$\mathrm{min}$ and the form, severity or degree of associated leukocytosis of the leukemia, nor between the concentration and the sex or age of the patient.
4. No obvious relationship was found to exist between the white cell concentration of thiamin and the apparent youth of the cells.

5. Patients with leukemia excrete normal amounts of both thiamin and PAYF in the urine.

6. The probable explanation for the high concentration of white cell total thiamin is thought to be an impaired utilization of the thiamin, and not an increased ingestion or faulty excretion of the vitamin, nor the apparent youth of the cells involved.

7. Elevated blood cell concentrations of total thiamin have been found in patients with diseases other than leukemia; namely, with Hodgkin's disease and cancer of the gastro-intestinal tract, but not in patients with portal hepatic cirrhosis.

\section{BIBLIOGRAPHY}

1. Gorham, A. T., Abels, J. C., Robbins, A. L., and Rhoads, C. P., The measurement and metabolism of thiamin and of a pyrimidine stimulating yeast fermentation found in the blood cells and urine of normal individuals. J. Clin. Invest., 1942, 21, 161.

2. Sinclair, H. M., Discussion on the clinical aspects of the vitamin B complex. Proc. Roy. Soc. Med., 1939, 32, 812.

3. Goodhart, R., and Sinclair, H. M., Deficiency of vitamin $B_{1}$ in man as determined by blood cocarboxylase. J. Biol. Chem., 1940, 132, 11.

4. Butler, A. M., and Cushman, M., Distribution of ascorbic acid in blood and its clinical significance. J. Clin. Invest., 1940, 19, 459.

5. Warren, C. O., The Pasteur effect in bone marrow. J. Cell. and Comp. Physiol. (In Press.)

6. MacLeod, J., and Rhoads, C. P., Metabolism of leukocytes in Ringer phosphate and in serum. Proc. Soc. Exper. Biol. and Med.; 1939, 41, 268.

7. Victor, J., and Wintersteiner, M. R., Studies in mouse leukemia. X. Metabolic differences between transmission lines of mouse lymphatic leukemia. Am. J. Cancer, 1934, 22, 56.

8. Victor, J., and Potter, J. S., Influence of transmitted leukemia on metabolism of uninfiltrated lymphoid tissue. Brit. J. Exper. Physiol., 1938, 19, 227.

9. Sabine, J. C., Choline esterase of blood cells and plasma in blood dyscrasias with special reference to pernicious anemia. J. Clin. Invest., 1940, 19, 833.

10. Vilter, S. P., Koch, M. B., and Spies, T. M., Coenzymes I and II in human blood. J. Lab. and Clin. Med., 1940, 26, 31. 